\title{
Co-activator p I 20 is increased by gonadotropins in the rat ovary and enhances progesterone receptor activity
} Miki Yoshino 1,2, Tetsuya Mizutani1,2, Kazuya Yamada1,2, Takashi Yazawa1,2, Hiroko Ogata-Kawata1,2, Toshio Sekiguchi1,2, Takashi Kajitani ${ }^{1,2}$ and Kaoru Miyamoto*1,2

Address: ${ }^{1}$ Department of Biochemistry, Faculty of Medical Sciences, University of Fukui, Shimoaizuki, Matsuoka, Fukui 910-1193, Japan and ${ }^{2}$ CREST, JST (Japan Science and Technology), Japan

Email: Miki Yoshino - yoshino@fmsrsa.fukui-med.ac.jp; Tetsuya Mizutani - mizutani@fmsrsa.fukui-med.ac.jp; Kazuya Yamada - kazuya@fmsrsa.fukui-med.ac.jp; Takashi Yazawa - yazawa@fmsrsa.fukui-med.ac.jp; Hiroko OgataKawata-hirozou@fmsrsa.fukui-med.ac.jp; Toshio Sekiguchi - toshio@fmsrsa.fukui-med.ac.jp; Takashi Kajitani - kajitani@fmsrsa.fukuimed.ac.jp; Kaoru Miyamoto* - kmiyamot@fmsrsa.fukui-med.ac.jp

* Corresponding author

Published: 03 October 2006

Reproductive Biology and Endocrinology 2006, 4:50 doi:10.1 186/1477-7827-4-50

This article is available from: http://www.rbej.com/content/4/I/50

(c) 2006 Yoshino et al; licensee BioMed Central Ltd.

This is an Open Access article distributed under the terms of the Creative Commons Attribution License (http://creativecommons.org/licenses/by/2.0), which permits unrestricted use, distribution, and reproduction in any medium, provided the original work is properly cited.

\begin{abstract}
Background: Ovarian follicular development is primarily dependent on pituitary gonadotropins. Identification of gonadotropin-inducible genes in the ovary is one of the effective approaches for the study of follicular development. In this study we identify rat homologue of $\mathrm{p} / 20$, a nuclear transcription co-activator, as one of the FSH inducible genes in the rat granulosa cells.

Methods: A full-length cDNA encoding rat pl 20 was cloned, and expression of the gene in the ovary was examined by Northern blotting. Tissue localization of p 120 was examined by in situ hybridization. Cellular functions of $\mathrm{p} / 20$ were studied by co-transfection of rat $\mathrm{p} / 20$ gene together with estrogen receptor (ER)-alpha, ER-beta, androgen receptor (AR), or progesterone receptor (PR) genes.

Results: A full-length cDNA encoding rat p 120 was characterized as a protein with 957 amino acid residues. Rat p 120 was expressed ubiquitously, but strongly in the ovary and the testis. Expression of p 120 mRNA was also induced in vivo by PMSG or PMSG/hCG treatment. Strong expression of pI 20 mRNA was observed in the granulosa cells of pre-ovulatory large antral follicles. Progesterone receptor was co-localized with p/20 in the large antral follicles. Co-transfection experiments revealed that rat pI 20 activated AR, ER-alpha, ER-beta, and PR in the presence of their respective ligands.
\end{abstract}

Conclusion: These observations suggest that rat $\mathrm{p} / 20$ is strongly induced in the ovarian granulosa cells, and may work together with PR in the granulosa cells of ovulatory follicles to promote the ovulation process. 


\section{Background}

Follicular growth is primarily controlled by pituitary gonadotropins $\mathrm{LH}$ and FSH in assistance with various intraovarian factors that also play essential and significant roles in development. FSH stimulates proliferation and differentiation of granulosa cells of small follicles in the ovary, and promotes their development to pre-ovulatory follicles [1-3]. During the differentiation of the granulosa cells, steroid hormone synthesizing enzymes are induced in the cells [4]. Estrogen and progesterone produced in the ovary work primarily on the uterus or the mammary gland, but the steroids also regulate pituitary gonadotropin secretion through positive and negative feedback systems of hypothalamus-pituitary-ganadal axis [5]. These steroid hormones also work on the ovary in either a paracrine or an autocrine fashion [6]. Progesterone is known to be involved in the ovulation process $[7,8]$, and estrogen receptor knockout results in the malfunction of the mouse ovary [9]. Deficiencies of progesterone receptors or estrogen receptors result in various defects of reproductive functions, such as abnormal follicular development, anovulation, and infertility [10-12]. Both estrogen and progesterone receptors belong to the nuclear receptor superfamily proteins that activate the transcription of their target genes when the steroid hormones or ligands bind to them $[12,13]$. The nuclear hormone receptors generally bind to the respective hormone responsive elements (HREs) within the upstream regions of the target genes, and activate their transcription [14-16]. Co-activators are required to form active protein complexes with the hormone nuclear receptors and the basic transcription machinery proteins for the target gene transcription $[17,18]$. Co-activators p160/SRC and CBP/p300 are known to interact with the nuclear hormone receptors at the C-terminal AF-2 region through the LXXLL-motif (NR box) [19-21]. Knockout mice of steroid receptor co-activator 3 (SRC-3), a member of p160 family, exhibit infertility [22], and those of nuclear receptor interacting protein 1 (Nrip1/RIP140) are also infertile due to the blockage of the oocyte release from the Graafian follicles by the ovulatory stimuli [23]. These reports indicate that co-activators are also important for follicular development and ovulation. Recently we identified many gonadotropin inducible genes expressed in the ovary by subtraction cloning and DNA microarray analyses, and found that p120, a member of nuclear co-activators, was strongly induced in the rat cultured granulosa cells by FSH. The coactivator p120 was originally isolated as a novel nuclear co-activator for thyroid hormone receptor [24]. Further studies revealed that p120 also interacts with 9-cis-retinoic acid receptor (RXR) functioning as a co-activator of these nuclear receptors [25]. In this study, we examined expression and localization of $\mathrm{p} 120$ gene in the ovary during the follicular development. In addition, we examined functions of rat p120 as a nuclear co-activator by transfec- tion experiments, and showed that $\mathrm{p} 120$ may promote the function of the progesterone receptors in the ovary during the ovulation.

\section{Materials and methods Materials}

The Oligotex dT-30 super, T7- and SP6-RNA polymerases were obtained from Roche Molecular Biochemicals (Mannheim, Germany). The TRIZOL reagent, an RNase inhibitor, a Superscript II reverse transcriptase, an expression vector pcDNA3, and a Lipofectamine PLUS reagent were obtained from Invitrogen (Groningen, Netherlands). The dual luciferase reporter assay system, a pGEM-T Easy vector, and pGL3-Basic and pRL-CMV vectors were purchased from Promega (Madison, WI). A PCR-selected cDNA subtraction kit and ExpressHyb, a hybridization solution, were purchased from Clontech (Palo Alto, CA). The QIAGEN plasmid kit was purchased from QIAGEN (Hilden, Germany). The TaKaRa $B c a$ BEST Labeling Kit was purchased from TaKaRa Shuzo (Kyoto, Japan). The [ganma${ }^{32} \mathrm{P}$ ] deoxycytidine triphosphate (dCTP; $111 \mathrm{TBq} / \mathrm{mmol}$ ) and $\left.{ }^{35} \mathrm{~S}\right]$ cytidine triphosphate (CTP; $46.2 \mathrm{TBq} / \mathrm{mmol}$ ) were obtained from NEN Life Science Products (Wilmington, DE). The Fluorolinks Cy3-dCTP and Cy5-dCTP were purchased from Amersham Pharmacia Biotech (Arlington Heights, IL). Ovine FSH and human CG were obtained from the National Hormone and Pituitary Distribution Program (Bethesda, MD). Pregnant mare's serum gonadotropin (PMSG) was a product from Teikokuzouki, Inc. (Tokyo, Japan). Diethylstilbestrol (DES) was purchased from Sigma (St. Louis, MO).

\section{Animals}

Immature Wistar female rats (21 days old) were used. In order to obtain granulosa cells for primary culture, rats were treated with $2 \mathrm{mg}$ DES in $0.1 \mathrm{ml}$ of sesame oil once daily for 4 days to stimulate the proliferation of the cells. Cells were harvested, and primary culture was performed as reported previously [26]. For Northern blotting and in situ hybridization, rats were treated with either 30 IU of PMSG or with the same treatment for $48 \mathrm{~h}$ followed by the administration of 10 IU of hCG. At all times, the animals were treated according to National Institutes of Health guidelines.

\section{Subtraction cloning and DNA microarray}

In order to identify the granulosa cell-differentiation related genes, subtraction cloning and DNA microarray analyses were performed. Rat granulosa cells in the primary culture under serum-free conditions are known to undergo cell differentiation from 12 to $24 \mathrm{~h}$ after FSH treatment. Therefore, cultured granulosa cells in $50 \mathrm{~mm}$ dishes containing $5.0 \times 10^{6}$ viable cells were treated with or without $30 \mathrm{ng} / \mathrm{ml} \mathrm{FSH}$ for $15 \mathrm{~h}$. Messenger RNAs from FSH treated cells as well as control cells were then 
extracted. They were converted to double stranded cDNAs, and subtraction cloning was performed as previously reported [27]. Resulting cDNAs of size-range between 0.5 - $2.0 \mathrm{~kb}$ long were isolated and cloned into a pGEM-T easy vector to construct a subtraction plasmid cDNA library. About 400 clones in the plasmid library were randomly picked up and their nucleotide sequences were partially determined.

For DNA microarray analysis, mRNAs from the cells treated with or without FSH were labeled with fluorescent dyes, Cy3 and Cy5, respectively. Labeling reaction were performed at $37^{\circ} \mathrm{C}$ for $1 \mathrm{~h}$ in the dark in a 30 microliter reaction mixture that contained $50 \mathrm{mM}$ Tris- $\mathrm{HCl}(\mathrm{pH}$ 8.3), $75 \mathrm{mM} \mathrm{KCl}, 3 \mathrm{mM} \mathrm{MgCl}{ }_{2}, 10 \mathrm{mM}$ DTT, $2.5 \mathrm{mM}$ Fluorolink Cy3- or Cy5-dCTP, dNTP mix (0.5 mM dATP, $0.5 \mathrm{mM}$ dGTP, $0.5 \mathrm{mM}$ dTTP and $0.2 \mathrm{mM} \mathrm{dCTP}), 600$ units of Superscript II, 1.5 micrograms of mRNA and 1 microgram of oligo dT primer. Labeled cDNA probes were neutralized with $2 \mathrm{mM}$ EDTA, $0.1 \mathrm{~N} \mathrm{NaOH}$ and $0.1 \mathrm{~N} \mathrm{HCl}$ and purified with Microcon YM-30 (Millipore, USA). The labeled cDNA pools were denatured by boiling at $95^{\circ} \mathrm{C}$ for 2 min with $4 \times$ SSC, $25 \times$ Denhartd's and $0.2 \%$ SDS, and then mixed and hybridized to microarray glass slides containing 3200 cDNA elements (HyperGene Rat cDNA, DNA Chip Research Inc. Japan).

\section{Cloning and nucleotide sequence of full length cDNA for rat $p / 20$}

In order to isolate full-length cDNA clones for rat p120, a cDNA library of rat granulosa cells was screened with a 32P-labeled 750 bp fragment of rat p120 (NM_001008509). Ten positive clones were isolated from 10,000 cDNA clones. Nucleotide sequence of one clone among them was determined from both ends by the dye terminator cycle sequencing method using an automated DNA sequencer.

\section{Plasmids}

A human p120 (hp120/pKCR2) cDNA construct was kindly provided by Dr. Monden (Gunma University, Japan) [24]. A GRE-Luc reporter (cGREx2/pGL3-TK), human androgen receptor (hAR/pSG5), and a human progesterone receptor (hPR/pcDNA3) cDNA constructs were kindly provided by Dr. Kato (The University of Tokyo, Japan) [28]. An ERE-Luc reporter (ERE-TATA/ pGL2) and estrogen receptor-alpha (rER-alpha/pSG5) cDNA constructs were kindly provided by Dr. Maruyama (Yamanouchi Pharm.Co.Ltd, Tokyo, Japan) [29]. A rat estrogen receptor-beta (rER-beta/pSV2) cDNA construct was kindly provided by Dr. Muramatsu (Research Center for Genomic Medicine, Saitama Medical School, Japan) [30]. All of the reporter plasmids were authenticated by DNA sequencing.

\section{Reverse transcription (RT) and polymerase chain reaction (PCR) of rat $p / 20$}

Total RNA was isolated from various tissues using the TRIZOL reagent. Reverse transcription (RT) was performed at $37^{\circ} \mathrm{C}$ for $1 \mathrm{~h}$ in a 20 microliter reaction mixture that contained $50 \mathrm{mM}$ Tris-HCl ( $\mathrm{pH} 8.3), 75 \mathrm{mM} \mathrm{KCl}, 3 \mathrm{mM}$ $\mathrm{MgCl}_{2}, 0.5 \mathrm{mM}$ dNTPs, $10 \mathrm{mM}$ DTT, 200 units of Superscript II, 1 microgram of total RNA and 100 pmol of random hexamer. PCR was then performed using 50 microliter reaction mixture containing $2 \mathrm{mM}$ Tris $-\mathrm{HCl}$ (pH8.0), $10 \mathrm{mM} \mathrm{KCl}, 2 \mathrm{mM} \mathrm{MgCl} 2,0.2 \mathrm{mM}$ dNTPs, 10 pmol of PCR primers, 2 microliters of the reverse transcription product as a template, and 1.5 units of EXTaq DNA polymerase. The PCR was conducted at $94^{\circ} \mathrm{C}$ for 2 min, followed by 24 cycles $94^{\circ} \mathrm{C}$ for $20 \mathrm{sec}, 54^{\circ} \mathrm{C}$ for 30 sec and $72^{\circ} \mathrm{C}$ for $45 \mathrm{sec}$. DNA fragments were amplified using a specific $5^{\prime}$ - primer (CGCAAACTGACTGCTGAGAGAGTT, NM_001008509, 385-408) and a specific 3'primer (CAGAGGTAGCCTCTTCCATAGTGG, NM_001008509, 710-733).

\section{Northern blotting}

For Northern blot analysis, 10 micrograms of total RNA was separated by electrophoresis on a $1 \%$ denaturing agarose gel, transferred to a nylon membrane (Biodyne, ICN Biomedicals, INC., Glen Cove, NY), and cross-linked by UV irradiation. Complementary DNA Fragments of p120, ER-alpha, ER-beta and PR, were radio-labeled using the $\mathrm{Bca}$ BEST DNA Labeling Kit, and the labeled products were used as the probe. The membrane was hybridized at $68^{\circ} \mathrm{C}$ for $1 \mathrm{~h}$ in the ExpressHyb hybridization solution with a ${ }^{32} \mathrm{P}$-labeled probe. The membrane was washed twice at $50^{\circ} \mathrm{C}$ for $40 \mathrm{~min}$ in $0.1 \times \mathrm{SSC}$ and $0.1 \%$ SDS. The blot was also hybridized with a radio-labeled probe specific for rat glyceraldehyde 3-phosphate dehydrogenase (GAPDH) or acidic ribosomal phosphoprotein PO (36B4).

\section{Quantitative Real-time PCR}

Total RNA was isolated from cultured granulosa cells using the TRIZOL reagent. Five micrograms of total RNA was reverse-transcribed and prepared single strand cDNA molecules. As an internal standard, TATA binding protein (TBP) was used. PCR reaction was performed using Power SYBR Green PCR Master Mix (Applied Biosystems). Serial dilutions of the templates were prepared and the relative standard curve method was used to quantitate mRNA levels for each target gene[31]. Each real-time RT-PCR was performed in a 25 microliter final volume containing 1.25 U/microliter of MultiScribe RT, $300 \mathrm{nM}$ each forward and reverse primer. Specific primers used were; rat p120 (5'GCCTGGAGGAGCCTAAGGA, 3'-TATGTATACTAAAGCCATCATCGCTTTC), ERß (5'-TGCCCTGGTCTGGGTGAT, 3'-TGATGTGCCTGACGTGAGAAAG), PR (5'-TCAAGGCAATTGGCTTAAGACA, 3'-GAGCTGTT- 
TCACAAGATCATGCA), and TBP (5'-TGCACAGGAGCCAAGAGTGAA, 3'-CACATCACAGCTCCCCACCA). Statistical analyses were carried out by analysis of variance. Differences between groups were evaluated with Duncan multiple comparison test. Data are expressed as mean \pm SEM and $\mathrm{P}<0.05$ is considered significant.

\section{Transfection}

CV-1 cells, originated from an African green monkey kidney cell, were maintained in Dullbecco's modified Eagle's medium supplemented with $10 \%$ fetal bovine serum and antibiotics in a humidified atmosphere containing 5\% $\mathrm{CO}_{2}$ and $95 \%$ air at $37^{\circ} \mathrm{C}$. Transfection was performed using the Lipofectamine PLUS reagent. All plasmids used for transfection were prepared using a QIAGEN plasmid kit, and purified by $\mathrm{CsCl}$ gradient ultracentrifugation. Cells $\left(2 \times 10^{5}\right)$ were dispensed into 24-well plates and cultured for $24 \mathrm{~h}$ prior to transfection. DNA samples which contained each reporter plasmid and the pRL Renilla luciferase control vector (for normalization) with or without expression plasmids (hAR/pSG5, hPR-B/pcDNA3, rERalpha/pSV2 or rER-beta/pSG5) were mixed and added to the cells in hormone-free conditions. Three hours after transfection, the medium was changed. Twenty-four hours later, the cells were treated with a ligand for each steroid hormone receptor (10 $\mathrm{nM}$ or $100 \mathrm{nM}$ ) for $24 \mathrm{~h}$. Cells were harvested $48 \mathrm{~h}$ after the transfection. Measurements were made using a Lumat LB9501 luminometer (Berthold) in a single tube, with the first assay for firefly luciferase followed by the Renilla luciferase assay. Firefly luciferase activities (relative light units) were normalized to Renilla luciferase activities.

\section{In situ hybridization of rat $p / 20$}

Rat ovaries were embedded into compounds and frozen in liquid nitrogen. Fourteen micrometer thick sections were cut by a cryostat and mounted on silane-coated glass slides for in situ hybridization. The sections were fixed in 4\% paraformaldehyde in PBS for $15 \mathrm{~min}$, washed with PBT (PBT: PBS plus $0.1 \%$ Tween-20), and acetylated in
$0.25 \%$ acetic-anhydride in TEA (0.1 M Triethanolamine, $0.15 \mathrm{M} \mathrm{NaCl} \mathrm{pH8.0)} \mathrm{for} 10 \mathrm{~min}$, and washed again with PBT. They were then dehydrated through ethanol step series (70-100\%) and dried. Complementary DNA Frangments of rat p120 (AB180485, 385-733), ER-beta (NM012754, 49-584) and PR (NM022847, 2137-2697) were subcloned into the pGEM-T easy vector, respectively, and antisense or sense [ ${ }^{35} \mathrm{~S}$ ] CTP-labeled RNA probes were synthesized using T7 or SP6 RNA polymerase. The samples were hybridized and washed at high stringency and autoradiographed with the emulsion of NTB2 (Eastman Kodak Co., Rochester, NY). All slides were counterstained with hematoxylin, dehydrated, and mounted.

\section{Results}

In order to isolate FSH inducible genes in cultured rat granulosa cells, a subtraction cloning and DNA microarray analyses were performed. Hundreds of candidate genes were picked-up and 10 genes among them were confirmed as FSH inducible by semi-quantitative RT- PCR analysis (Table. 1). As shown in Fig. 1, RT-PCR revealed that p120 was expressed ubiquitously, but strong expression of the mRNA was observed in the ovary (lane 11) and the testis (lane 6). PMSG treatment increased the p120 expression of mRNA after $48 \mathrm{~h}$ (lane 12), indicating that p120 was also induced in the ovary in vivo.

We then cloned a full-length cDNA encoding p120 and the nucleotide sequence was determined. Fig. 2 shows the deduced amino acid sequence of rat p120, which is compared with that of human p120. It contains proline-rich, acidic, and bromo-domains, respectively, and there are two LXXLL-motifs between proline-rich and acidic domains. The sequences are well conserved between rat and human ( $94 \%$ identity at amino acid level), except that rat p120 has 45 amino acid residues extended at $\mathrm{N}$-terminus.

Gene expression of p120 in the cultured rat granulosa cells was analyzed by Northern blotting (Fig. 3) and real-

Table I: Induced genes in the rat granulosa cells stimulated with FSH for $15 \mathbf{~ h}$.

\begin{tabular}{ll}
\hline Accession & Definition \\
\hline ABI80485 & Human thyroid hormone receptor coactivating protein like protein (rat pl20) \\
ABI809I2 & Unknown serine protease like protein \\
U23776 & Rat Eker rat-associated intracisternal-A particle element \\
NM_0I2600 & Rat Malic enzyme I, soluble (Mel) \\
AY009092 & Rat retrovirus SCI \\
NM_0II462 & Mouse spindlin (Spin) \\
NM_019683 & Mouse globin inducing factor, fetal (Gbif-pending) \\
M64393 & Rat 3-alpha-hydroxysteroid dehydrogenase (3-alpha-HSD) \\
NM_022265 & Rat programmed cell death 4 (Pdcd4) \\
NM_017290 & Rat ATPase, Ca++ transporting, cardiac muscle, slow twitch 2 (Atp2a2) \\
\hline
\end{tabular}




\section{rat $\mathrm{p} 120$}

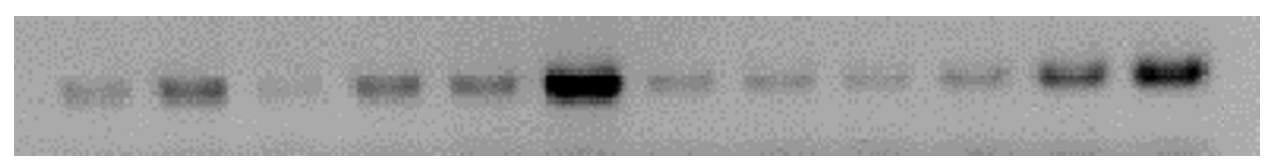

GAPDH

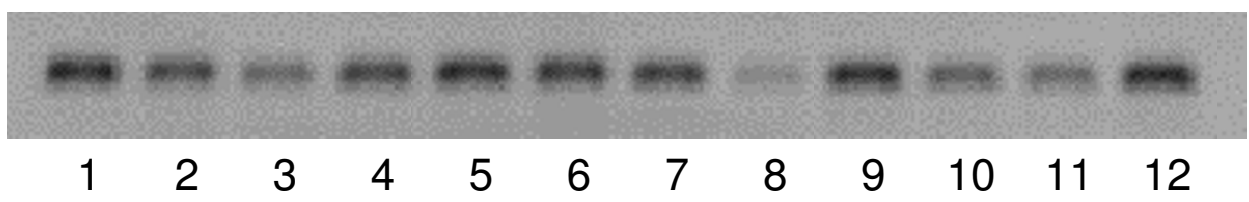

\section{Figure I}

Tissue Distribution of rat p I20 RT- PCR was performed using p 20 specific primers. Total RNA was isolated from various tissues of adult rats. Ten micrograms of total, extracted RNA were reverse-transcribed, and a portion (I/I00) was subjected to the PCR reaction for the specific amplification of p I 20 and GAPDH, respectively. The reaction mixtures were separated I.5\% agarose gel and visualized with EtBr staining. The samples are brain (lane I), pituitary (lane 2), liver (lane 3), adrenal (lane 4), uterus (lane 5), testis (lane 6), kidney (lane 7), spleen (lane 8), intestine (lane 9), stomach (lane 10), untreated ovary (lane II), ovary treated with PMSG for $48 \mathrm{~h}$ (lane I2).

time RT-PCR (Fig. 4). Rat granulosa cells cultured under serum free conditions were treated with $30 \mathrm{ng} / \mathrm{ml}$ of FSH. Gene expression of p120 was rapidly induced by the FSH treatment within $1 \mathrm{~h}$, with a transient peak at $2 \mathrm{~h}$, and increased again $24 \mathrm{~h}$ after the treatment. The treatment of immature rats with PMSG in vivo also induced the gene expression of p120 in the ovary with a transient peak at 6 $\mathrm{h}$ after the treatment, and then the gene expression was increased again $24 \mathrm{~h}$ after the treatment. Gene expression level of estrogen receptor-alpha (ER-alpha) in the ovary of immature rat was very low even after the PMSG treatment. On the other hand, ER-beta was induced in the ovary by the PMSG treatment. The hCG administration $48 \mathrm{~h}$ after the PMSG treatment further increased the p120 gene expression. Levels of progesterone receptor (PR), which is known as one of the ovulation related genes, were also shown. These two genes, p120 and PR, showed similar mRNA expression patterns.

In order to verify the co-activator function of rat and human p120, co-transfection experiments were done using various steroid hormone receptor genes and reporter genes. CV-1 cells were co-transfected with a luciferase reporter vector and steroid hormone receptor cDNA expression vectors in the presence or absence of their ligand steroid hormones. As shown in Fig. 5a, luciferase activities were increased by the addition of either testosterone propionate or progesterone when AR or PR expression vectors were co-transfected to the cells, respectively. Co-transfection of a human p120 expression vector further increased the luciferase activities in the presence of the ligands. Similarly, co-transfection of a rat p120 expression vector with either ER-alpha or ER-beta also increased the luciferase activities in the presence of estradiol as shown in Fig. 5b. These observations clearly indicate that p120 works as a transcriptional co-activator of androgen, progesterone and estrogen receptors.

Localization of rat p120, ER-beta and PR in the ovary was examined by in situ hybridization using adjacent frozen sections as shown in Fig. 6A-D. Immature female rats were treated either with PMSG or PMSG/hCG. Gene expression of p120 was weakly detected throughout the ovary of untreated rats (a, b), whereas ER-beta was expressed predominantly in the granulosa cells of small preantral and antral follicles of untreated rats $(c, d)$. Strong gene expression of p120 both in granulosa and theca cells was observed $6 \mathrm{~h}$ after the PMSG treatment (e, f), whereas ER-beta was expressed mainly in the granulosa cells of small and midsize follicles $(h, i)$, indicating that p120 and ER-beta are partly co-localized in the ovary $6 \mathrm{~h}$ after the PMSG stimulation. Gene expression of p120 was also observed in the stroma. However $24 \mathrm{~h}$ after the PMSG treatment, p120 was strongly expressed in the granulosa cells of large antral follicles where practically no expression of ER-beta mRNA was observed as shown in Fig. 6C $(\mathrm{k}-\mathrm{n})$. In addition, a level of p120 was gradually decreased $48 \mathrm{~h}$ after the PMSG treatment (data not shown), but by the following treatment with hCG, strong expression of p120 mRNA was re-induced in the granulosa cells of large antral follicles $4 \mathrm{~h}$ after the treatment $(\mathrm{o}, \mathrm{p})$. The hCG treatment was a typical protocol for the induction of ovulation from large antral follicles. This was confirmed by the fact that expression of PR mRNA, that is known to be induced in the ovulatory follicles just before the ovulation, was induced by the hCG treatment in the granulosa 


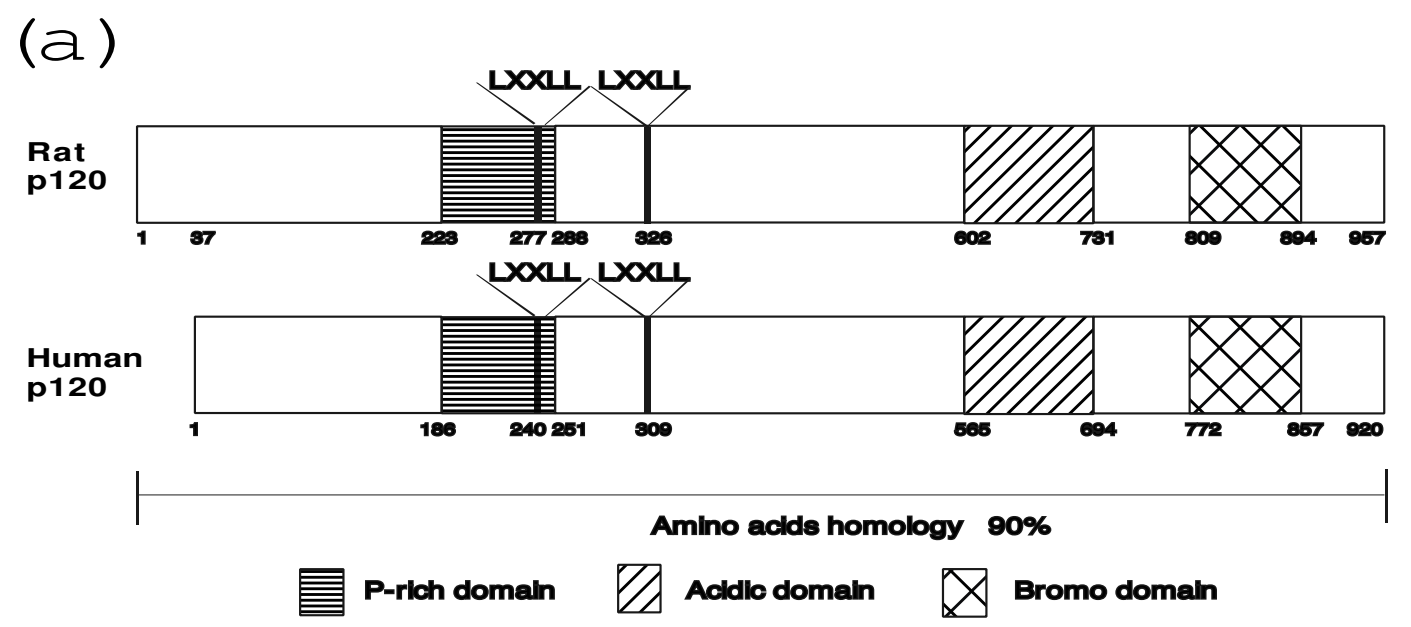

\section{(b)}

\begin{tabular}{|c|c|c|c|c|c|c|c|}
\hline $\begin{array}{l}\mathrm{t} \\
\operatorname{man}\end{array}$ & 1 & LCS & $\mathrm{PPL}$ & SFR & $\begin{array}{r}\text { PGSNSGCR } \\
\text { MRS }\end{array}$ & $\begin{array}{l}\text { FRTRVSVSR } \\
\text { DQNW } \mathrm{DQN* \star \star \star *}\end{array}$ & 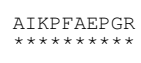 \\
\hline & $\begin{array}{l}61 \\
24\end{array}$ & $\mathrm{KHC}$ & 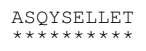 & TETPKRKRGE & KGEVVETVED & $\underset{E * \star}{E R R}$ & IKE \\
\hline & $\begin{array}{r}121 \\
84\end{array}$ & & * & D & E & & \\
\hline & $\begin{array}{l}181 \\
144\end{array}$ & TVM & $\begin{array}{l}\text { RSPIDSASP } \\
\star \star \star \star \star \star \star \star \star \star\end{array}$ & GDLT & TTMEEATSG & TP & $\frac{D T}{* \star *}$ \\
\hline & $\begin{array}{l}241 \\
204\end{array}$ & PG & $\frac{\text { PMTPVTDDSP }}{\star \star \star \star \star \star \star \star \star \star \star ~}$ & $T$ & $P P S$ & $\frac{I_{K K}}{\star \star \star \star}$ & \\
\hline & $\begin{array}{l}30 \\
26\end{array}$ & TG & 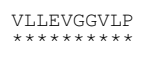 & & $\begin{array}{l}\text { A } \\
*\end{array}$ & 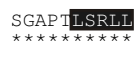 & \\
\hline & $\begin{array}{l}361 \\
324\end{array}$ & & $\begin{array}{l}\text { KLVPPPVV } \\
* \star \star \star * \star * \star *\end{array}$ & & $\underset{* \star \star \star * \star}{\text { APSSA }}$ & & \\
\hline & $\begin{array}{l}42 \\
38\end{array}$ & 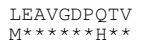 & & & RSG & & \\
\hline & & & תחת & & $\begin{array}{l}\text { LDVAAAVEA } \\
* * * * * * * *\end{array}$ & NDD & \\
\hline & & $\mathrm{KPV}$ & K & SE & KGIHELVDI & & \\
\hline 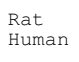 & $\begin{array}{l}601 \\
564\end{array}$ & ${ }^{* A}$ & *** & & ** & & \\
\hline & $\begin{array}{l}6 \\
62\end{array}$ & N & IEL & & EESGTIFGS & & \\
\hline & $\begin{array}{l}72 \\
68\end{array}$ & EPKEEDQG & * & & 㲾H & $\begin{array}{l}\text { PSSP } \\
\star \star \star \star *\end{array}$ & \\
\hline & $\begin{array}{l}7 \\
7\end{array}$ & 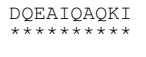 & 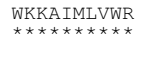 & AAAD & $\begin{array}{l}\text { FLQPVTDDIA } \\
* * * * * * * * *\end{array}$ & & $\frac{\mathrm{KKNI}}{\star \star \star \star \star}$ \\
\hline & & $E$ & 8 & DH & FMC & $\frac{Q F}{* *}$ & IMQTS \\
\hline 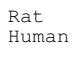 & 8 & 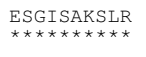 & $x \times x$ & $* * * * * \star * * *$ & $* *$ & ** & DMKMKK* \\
\hline
\end{tabular}

\section{Figure 2}

Structure of pl20. (a), Schematic illustrations of the structures of rat and human pl20. LXXLL motif (L, leucine; X, any amino acid). (b), A deduced amino acid sequence of rat p 20 . The amino acids are numbered starting from the initiation codon. The proline-rich domain between 223 and 288 amino acid residues from the $\mathrm{N}$-terminus is underlined, and acidic amino acid-rich domain between 602 and 731 is shown by bold type. The bromo-domain between 809 and 894 is boxed. The putative NR box (LXXLL motif) is boxed by colored background. 


\section{a. granulosa cell}

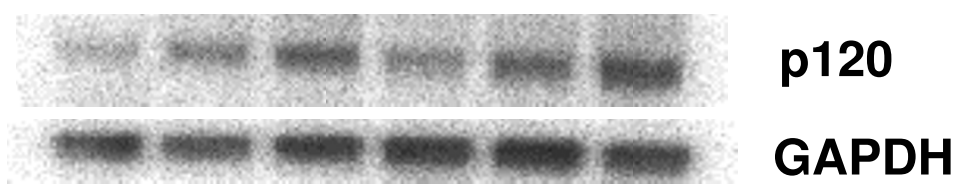

FSH

$\begin{array}{lllllll}0 & 1.5 & 3 & 6 & 12 & 24 & h\end{array}$

b. ovary

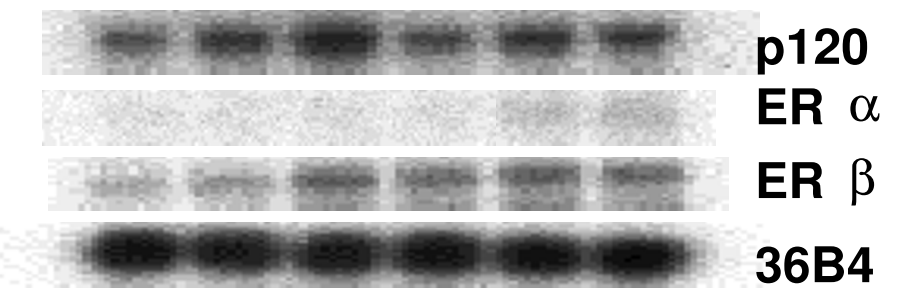

PMSG

$\begin{array}{lllllll}0 & 3 & 6 & 12 & 24 & 48 & h\end{array}$

c. ovary

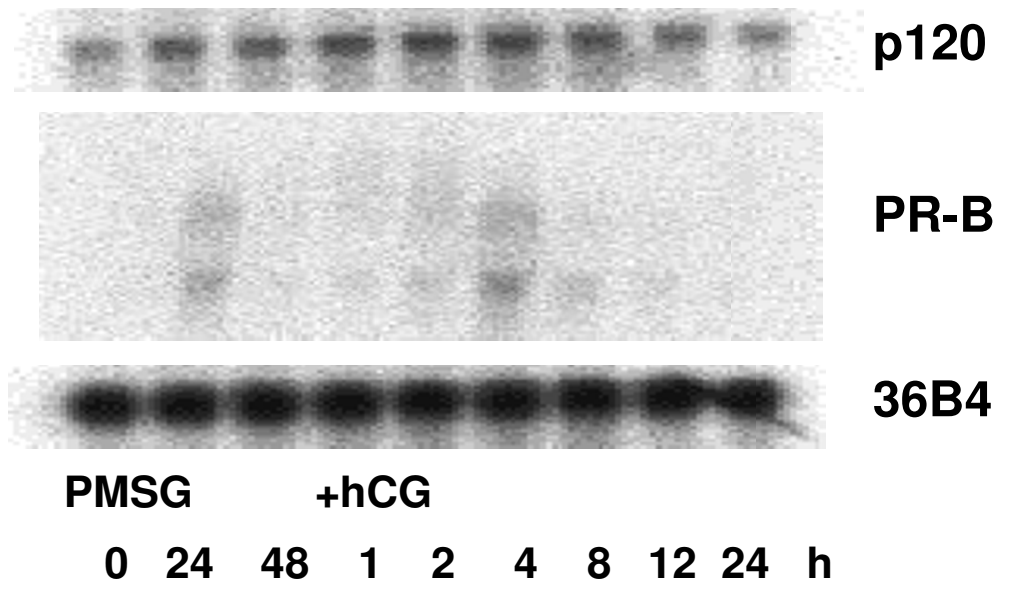

Figure 3

Induction of rat pl 20 gene expression in the ovary. Northern blot analysis of rat pI 20 mRNA in cultured granulosa cells treated with FSH (a), in immature rat ovary primed with PMSG (b), and in immature rat ovary primed with PMSG followed by hCG (c). Total RNA was isolated at the indicated times after the treatments. All samples contained 10 micrograms of total RNA. The blots were hybridized with each specific probe of rat pI20, ER-alpha, ER-beta, or PR, respectively. The blots were striped and rehybridized with a probe specific for GAPDH or 36B4 to normalize for equivalent loading of RNA. 
(a)FSH traetment
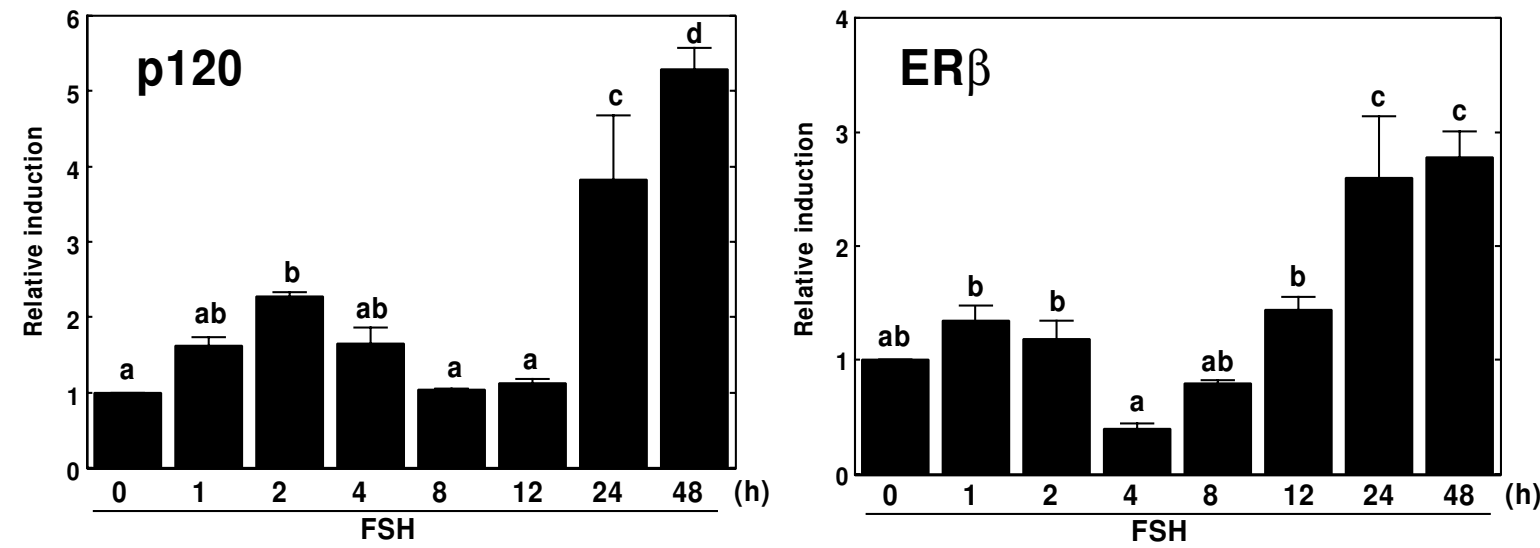

(b)FSH + hCG traetment

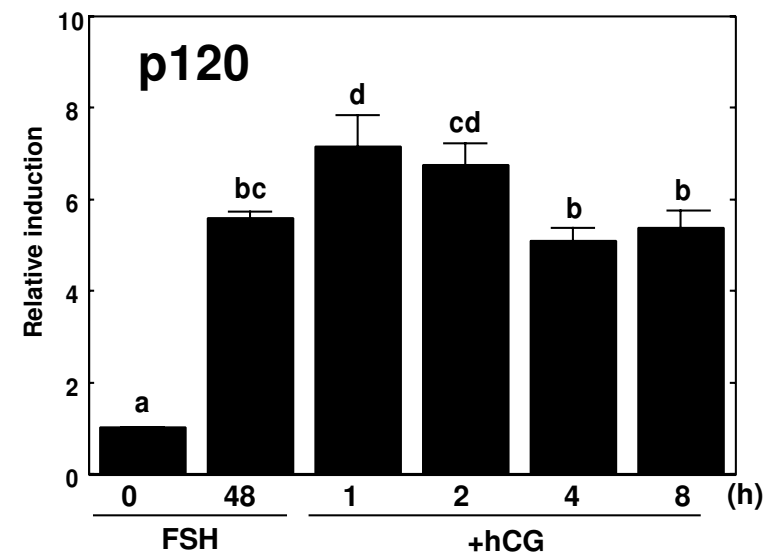

Figure 4

Induction of rat pl 20 gene expression in the ovary. Real-time PCR was performed using each specific primer of rat pl20, ERbeta, or PR, respectively. Total RNA was isolated from cultured granulosa cells treated with FSH for $48 \mathrm{hr}$ (a) or with FSH for $48 \mathrm{~h}$ followed by hCG (b). Each value represents the mean \pm SEM of 4 independent Real-time PCR experiments. Different letters for the same graph indicate statistically significant differences $(P<0.05$; Duncan multiple comparison test).

cells of the same large antral follicles that expressed p120 $(\mathrm{r}, \mathrm{s})$.

\section{Discussion}

As shown in Table 1, a rat homologue of co-activator, p120, was identified as one of the gonadotropin inducible genes in the ovarian granulosa cells. The co-activator p120 has been originally identified as a protein that interacts with thyroid hormone receptor (TR) -beta1 at the ligandbinding domain (LBD) [24]. Monden et al. reported that human p120 consists of 920 amino acid residues with two LXXLL motifs and a bromo-domain, and interacts with TR-beta1 and PPAR-gamma to increase their transcriptional activities [25]. The LXXLL-motifs are found in most co-activators such as RIP140, SRC-1, TIF-2 and CBP/p300, and is shown to interact with common AF-2 regions of nuclear hormone receptors $[19,20,32]$. The bromodomain motifs are also often found in co-activators, and are reported to be essential for exhibiting the full activity of p300 in terms of histone acetyltransferase (HAT) activity [33,34]. The bromo-domain motifs of Gen5p, PCAF, TAF250 and p300 are reported to interact directly with histone molecules [35-37]. In this study, we examined ability of p120 to activate various steroid hormone receptors. As shown in Fig. 5, p120 activated all the steroid hormone receptors examined in the presence of their ligand steroid hormones. This is consistent with the structural information described above. Therefore, together with the previous findings, p120 acts as a co-activator of most steroid hormone receptors. 


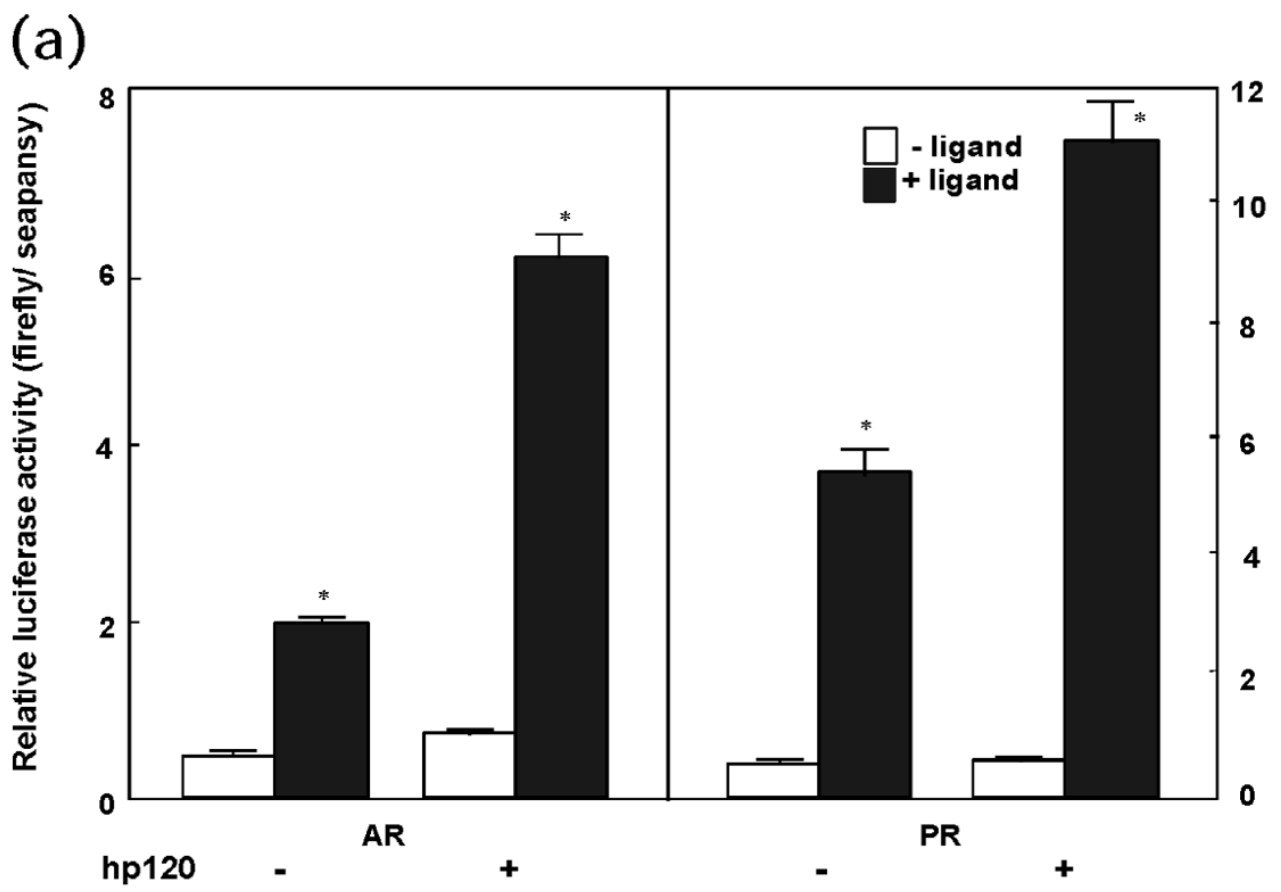

(b)

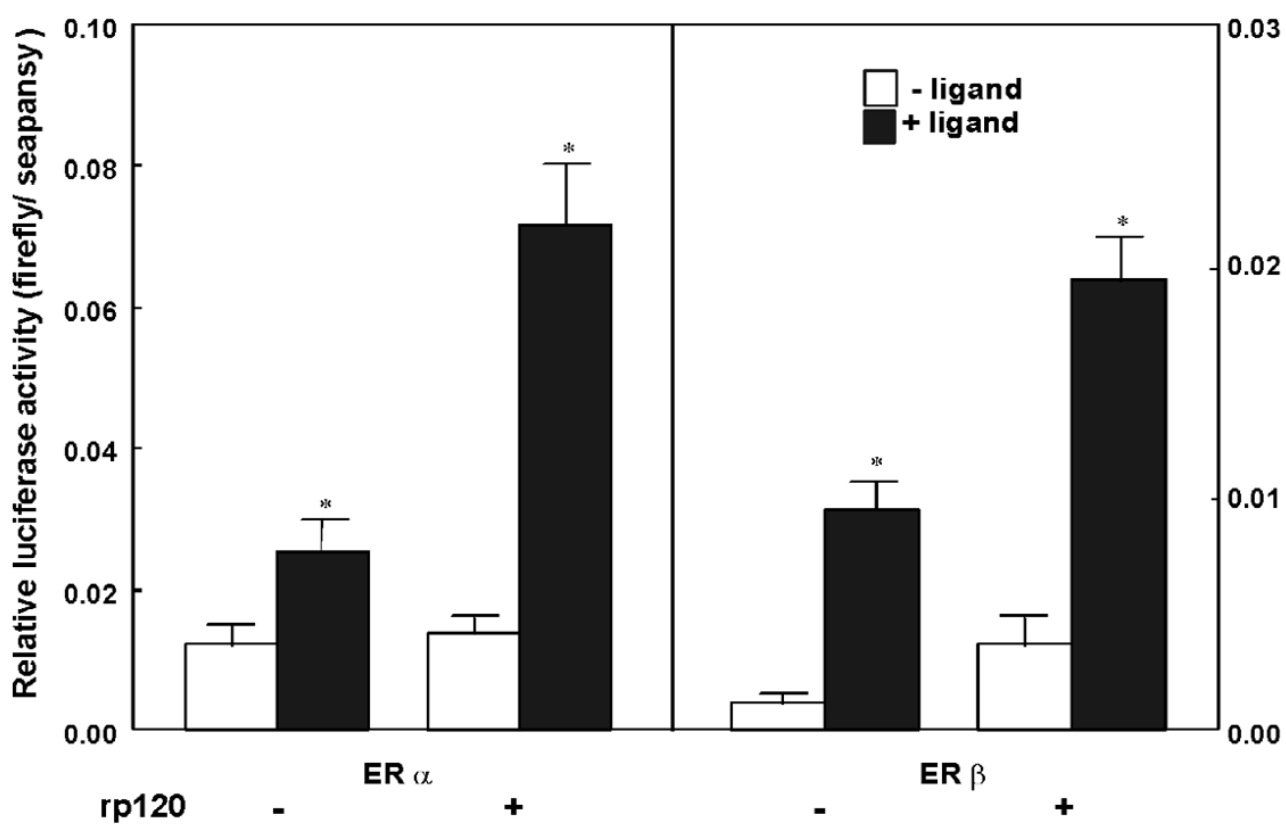

Figure 5

Activation of nuclear hormone receptors with p 120. CV-I cells were transfected as described in Materials and Methods with cGREx2/pGL3-TK and hAR (hAR/pSG5), or with cGREx2/pGL3-TK and hPR (hPR/pcDNA3) in the presence or absence of human pI 20 (a), ERE-TATA/pGL2 and rER-alpha (rER-alpha/pSV2), or ERE-TATA/pGL2 and rER-beta (rER-beta/pSG5) in the presence or absence of rat $\mathrm{p} \mid 20$ (b). Ligands for each nuclear receptor $\left(10^{-8} \mathrm{M}\right.$ testosterone propionate, $10^{-8} \mathrm{M}$ progesterone, $10^{-8} \mathrm{M}$ estradiol, and 10-7M estradiol) were also added to the cultures. Each value represents the mean \pm SEM of 4 independent transfection experiments. $* \mathrm{P}<0.01$ by Student's $t$ test. 


\section{(A) untreated}

(B) PMSG 6h

$$
\text { p120 }
$$<smiles>[10BH2]</smiles>
p120<smiles>[10BH2]</smiles>

antisense probe
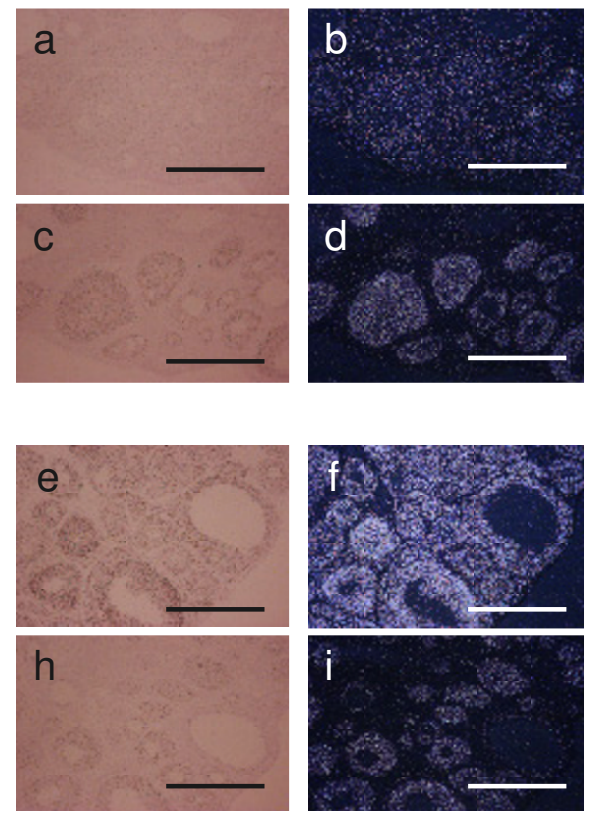

(C) PMSG 24h

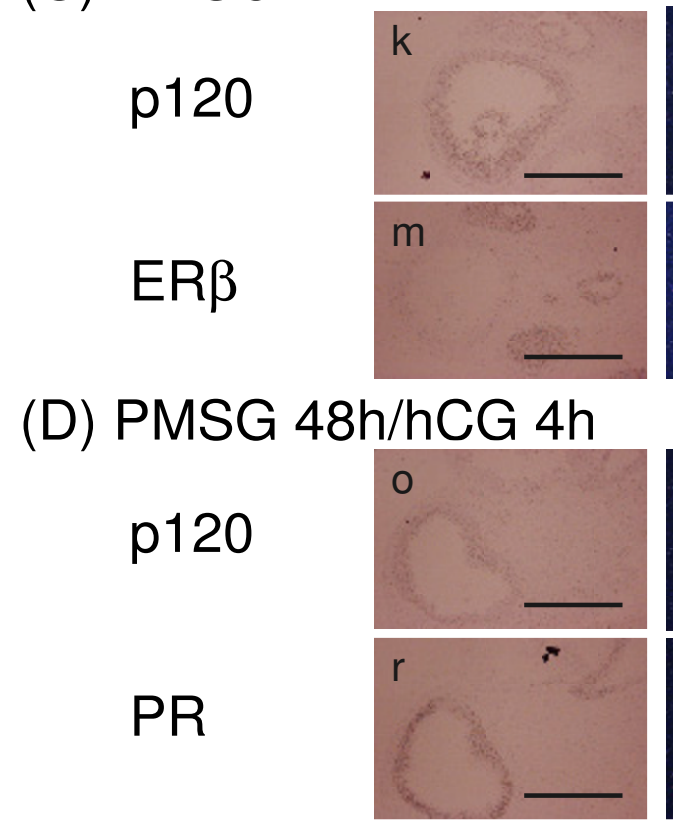

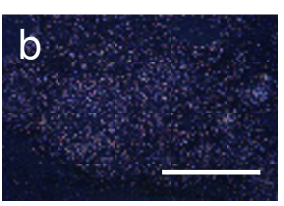
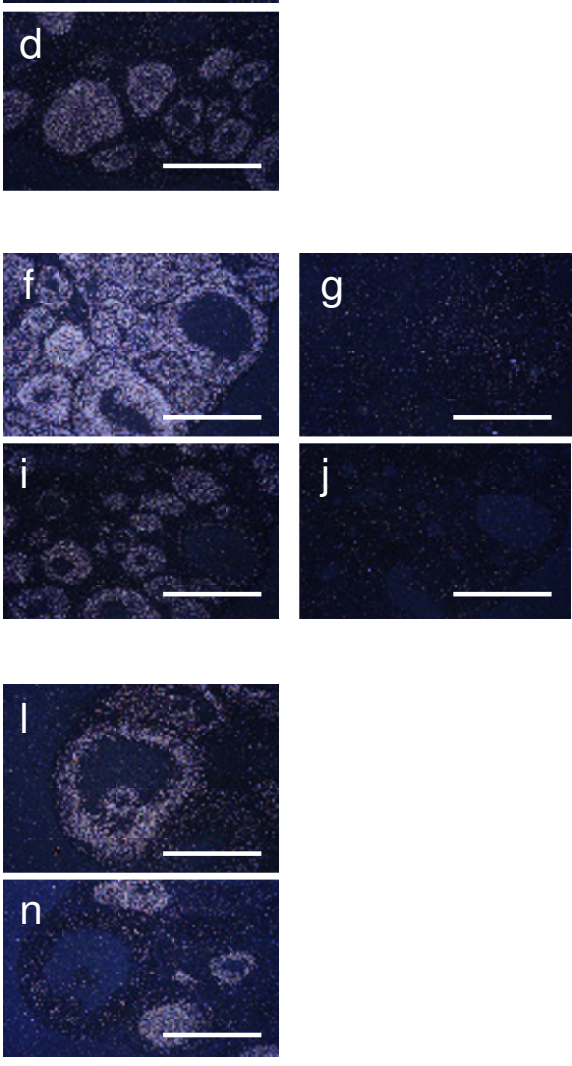

sense probe

\section{(1)}


Co-activators SRC-1 and $\mathrm{CBP} / \mathrm{p} 300$ are reported to be ubiquitously expressed, whereas TIF2 and Rip140 show some tissue specific expression [33,38,39]. Expression of rat p120 mRNA was observed in most tissues but was highest in gonads, suggesting some roles for gonadal functions. Knockout mice of steroid receptor co-activator 3 (SRC-3), a member of p160 family, exhibit infertility [22], and those of nuclear receptor interacting protein 1 (Nrip1/RIP140) are also infertile due to the blockage of the oocytes release from the Graafian follicles by the ovulatory stimuli [23]. These reports indicate that co-activators are also important for the follicular development and ovulation.

With respect to the function of steroid hormone receptors in the ovary, ER-beta and PR were expressed in the ovary in a gonadotropin dependent manner as demonstrated by Northern blotting and in situ hybridization. However, induction patterns of ER-beta and PR are quite different. Even after the PMSG stimulation, ER-beta gene expression was mainly observed in granulosa cells of pre-antral or small antral follicles, whereas expression of PR mRNA was found in the granulosa cells of large antral follicles after the stimulation. In situ hybridization revealed that the induction pattern of p120 was very similar to that of PR. It is well established that PR participates in the ovulation process occurring in the pre-ovulatory large antral follicles. Ovulation is triggered by LH surge from the pituitary. About $4 \mathrm{~h}$ after the LH surge, expression of PR mRNA is rapidly induced in the granulosa cells of pre-ovulatory large antral follicles destined to ovulate $[7,8]$. Progesterone binds to the induced receptor to activate gene expression of specific proteases, ADAMTS- 1 or Cathepsin L, which are thought to work on follicle rupture by degrading the ovulating follicle walls [40]. In addition, female PR knockout mice are infertile due to the blockage of ovulation $[12,41]$. In the present experiments, we showed that the induction and tissue distribution patterns of p120 and PR were very similar, and that p120 was able to enhance the transcriptional activity of PR in the presence of progesterone. It is likely that p120 may also be one of the co-activators that participate in the ovulation from pre-ovulatory follicles.

\section{Conclusion}

Rat p120 was strongly expressed in the granulosa cells of pre-ovulatory follicles by the stimulation with gonadotropins. Rat p120 was able to enhance the transcriptional activity of progesterone receptor in the presence of progesterone, and p120 co-localized with progesterone receptor in the pre-ovulatory follicles. These observations suggest that p120 may work together with PR in the granulosa cells of ovulatory follicles to promote the ovulatory process in the ovary.

\section{Authors' contributions}

MY participated in the histochemical studies, transfection of genes and moleculer analysis of genes. TM, KY, TY, HO, $\mathrm{TS}$, and TK participated in the moleculer analysis of genes. KM participated in the design of the study.

\section{Acknowledgements}

This work was supported in part by a grant from the Smoking Research Foundation, and by 2 Ist Century COE Program (Medical Science).

\section{References}

I. Richards JS, Fitzpatrick SL, Clemens JW, Morris JK, Alliston T, Sirois $\mathrm{J}$ : Ovarian cell differentiation: a cascade of multiple hormones, cellular signals, and regulated genes. Recent Prog Horm Res 1995, 50:223-254.

2. Richards JS, Russell DL, Robker RL, Dajee M, Alliston TN: Molecular mechanisms of ovulation and luteinization. Mol Cell Endocrinol 1998, I45(I-2):47-54.

3. Robker RL, Richards JS: Hormonal control of the cell cycle in ovarian cells: proliferation versus differentiation. Biol Reprod 1998, 59(3):476-482.

4. Richards JS: Hormonal control of gene expression in the ovary. Endocr Rev 1994, I 5(6):725-75।.

5. Roberts AJ, Skinner MK: Mesenchymal-epithelial cell interactions in the ovary: estrogen-induced theca cell steroidogenesis. Mol Cell Endocrinol 1990, 72(I):RI-5.

6. Katzenellenbogen BS, Nardulli AM, Read LD: Estrogen regulation of proliferation and hormonal modulation of estrogen and progesterone receptor biosynthesis and degradation in target cells. Prog clin biol res 1990, 322:201-2II.

7. Park OK, Mayo KE: Transient expression of progesterone receptor messenger RNA in ovarian granulosa cells after the preovulatory luteinizing hormone surge. Mol Endocrinol |991, 5(7):967-978.

8. Natraj U, Richards JS: Hormonal regulation, localization, and functional activity of the progesterone receptor in granulosa cells of rat preovulatory follicles. Endocrinology 1993, I33(2):76I-769.

9. Drummond $\mathrm{AE}$, Findlay JK: The role of estrogen in folliculogenesis. Mol Cell Endocrinol 1999, I 5 I (I-2):57-64.

10. Couse JF, Korach KS: Estrogen receptor null mice: what have we learned and where will they lead us? Endocr Rev 1999, 20(3):358-417.

II. Couse JF, Hewitt SC, Bunch DO, Sar M, Walker VR, Davis BJ, Korach KS: Postnatal sex reversal of the ovaries in mice lacking estrogen receptors alpha and beta. Science 1999, 286(5448):2328-233।.

12. Lydon JP, DeMayo FJ, Funk CR, Mani SK, Hughes AR, Montgomery CAJ, Shyamala G, Conneely OM, O'Malley BW: Mice lacking progesterone receptor exhibit pleiotropic reproductive abnormalities. Genes Dev 1995, 9(1 8):2266-2278.

13. Conneely OM, Mulac-Jericevic B, DeMayo F, Lydon JP, O'Malley BW: Reproductive functions of progesterone receptors. Recent Prog Horm Res 2002, 57:339-355.

14. Beato M, Sanchez-Pacheco A: Interaction of steroid hormone receptors with the transcription initiation complex. Endocr Rev 1996, 17(6):587-609.

15. Hadzic E, Desai-Yajnik V, Helmer E, Guo S, Wu S, Koudinova N, Casanova J, Raaka BM, Samuels HH: A I 0-amino-acid sequence in the $\mathrm{N}$-terminal A/B domain of thyroid hormone receptor alpha is essential for transcriptional activation and interaction with the general transcription factor TFIIB. Mol Cell Biol 1995, 15(8):4507-4517.

16. Schulman IG, Chakravarti D, Juguilon H, Romo A, Evans RM: Interactions between the retinoid $X$ receptor and a conserved region of the TATA-binding protein mediate hormonedependent transactivation. Proc Natl Acad Sci U S A 1995, 92(18):8288-8292.

17. Xu L, Glass CK, Rosenfeld MG: Coactivator and corepressor complexes in nuclear receptor function. Curr Opin Genet Dev 1999, 9(2): 140-147. 
18. McKenna NJ, Lanz RB, O'Malley BW: Nuclear receptor coregulators: cellular and molecular biology. Endocr Rev 1999, 20(3):32I-344.

19. Torchia J, Rose DW, Inostroza J, Kamei Y, Westin S, Glass CK, Rosenfeld MG: The transcriptional co-activator $\mathbf{p} / \mathrm{CIP}$ binds CBP and mediates nuclear-receptor function. Nature 1997, 387(6634):677-684.

20. Heery DM, Kalkhoven E, Hoare S, Parker MG: A signature motif in transcriptional co-activators mediates binding to nuclear receptors. Nature 1997, 387(6634):733-736.

21. Mclnerney EM, Rose DW, Flynn SE, Westin S, Mullen TM, Krones A, Inostroza J, Torchia J, Nolte RT, Assa-Munt N, Milburn MV, Glass CK, Rosenfeld MG: Determinants of coactivator LXXLL motif specificity in nuclear receptor transcriptional activation. Genes Dev 1998, I2(2I):3357-3368.

22. Xu J, Liao L, Ning G, Yoshida-Komiya H, Deng C, O'Malley BW: he steroid receptor coactivator SRC-3 (p/CIP/RAC3/AIB I/ ACTR/TRAM-I) is required for normal growth, puberty, female reproductive function, and mammary gland development. Proc Natl Acad Sci U S A 2000, 97( ( 2):6379-6384.

23. White R, Leonardsson G, Rosewell I, Ann JM, Milligan S, Parker M: The nuclear receptor co-repressor nripI (RIPI 40) is essential for female fertility. Nat Med 2000, 6(12):|368-1374.

24. Monden T, Wondisford FE, Hollenberg AN: Isolation and characterization of a novel ligand-dependent thyroid hormone receptor-coactivating protein. I Biol Chem 1997, 272(47):29834-2984I.

25. Monden T, Kishi M, Hosoya T, Satoh T, Wondisford FE, Hollenberg AN, Yamada M, Mori M: pI 20 acts as a specific coactivator for 9-cis-retinoic acid receptor $(R X R)$ on peroxisome proliferator-activated receptor-gamma/RXR heterodimers. Mol Endocrinol 1999, I3(10): 1695-1703.

26. Nakamura M, Minegishi T, Hasegawa $Y$, Nakamura K, Igarashi S, Ito I, Shinozaki H, Miyamoto K, Eto Y, lbuki Y: Effect of an activin A on follicle-stimulating hormone (FSH) receptor messenger ribonucleic acid levels and FSH receptor expressions in cultured rat granulosa cells. Endocrinology 1993, I33(2):538-544.

27. Mizutani T, Sonoda Y, Minegishi T, Wakabayashi K, Miyamoto K: Cloning, characterization, and cellular distribution of rat scavenger receptor class B type I (SRBI) in the ovary. Biochem Biophys Res Commun 1997, 234(2):499-505.

28. Matsui D, Sakari M, Sato T, Murayama A, Takada I, Kim M, Takeyama $\mathrm{K}$, Kato S: Transcriptional regulation of the mouse steroid 5alpha-reductase type II gene by progesterone in brain. Nucleic Acids Res 2002, 30(6): $1387-1393$.

29. Maruyama K, Endoh H, Sasaki-Iwaoka H, Kanou H, Shimaya E, Hashimoto $S$, Kato $S$, Kawashima $\mathrm{H}$ : A novel isoform of rat estrogen receptor beta with 18 amino acid insertion in the ligand binding domain as a putative dominant negative regular of estrogen action. Biochem Biophys Res Commun 1998, 246(I): 142-147.

30. Koike S, Sakai M, Muramatsu M: Molecular cloning and characterization of rat estrogen receptor cDNA. Nucleic Acids Res 1987, I 5(6):2499-25।3.

31. Jelaso AM, Lehigh-Shirey E, Predenkiewicz A, Means J, Ide CF: Aroclor 1254 alters morphology, survival, and gene expression in Xenopus laevis tadpoles. Environ Mol Mutagen 2002, 40(I):24-35.

32. L'Horset F, Dauvois S, Heery DM, Cavailles V, Parker MG: RIP-I 40 interacts with multiple nuclear receptors by means of two distinct sites. Mol Cell Biol 1996, I6(I I):6029-6036.

33. Kraus WL, Manning ET, Kadonaga JT: Biochemical analysis of distinct activation functions in p300 that enhance transcription initiation with chromatin templates. Mol Cell Biol 1999, 19(12):8|23-8|35.

34. Manning ET, Ikehara T, Ito T, Kadonaga JT, Kraus WL: p300 forms a stable, template-committed complex with chromatin: role for the bromodomain. Mol Cell Biol 200I, 2 I ( I 2):3876-3887.

35. Dhalluin C, Carlson JE, Zeng L, He C, Aggarwal AK, Zhou MM: Structure and ligand of a histone acetyltransferase bromodomain. Nature 1999, 399(6735):49|-496.

36. Owen DJ, Ornaghi P, Yang JC, Lowe N, Evans PR, Ballario P, Neuhaus $D$, Filetici $P$, Travers AA: The structural basis for the recognition of acetylated histone $\mathrm{H} 4$ by the bromodomain of histone acetyltransferase gcn5p. EMBO J 2000, 19(22):6|4|-6I49.

37. Jacobson RH, Ladurner AG, King DS, Tjian R: Structure and function of a human TAFII 250 double bromodomain module. Science 2000, 288(5470): | 422-1425.
38. Voegel JJ, Heine MJ, Zechel C, Chambon P, Gronemeyer H: TIF2, a $160 \mathrm{kDa}$ transcriptional mediator for the ligand-dependent activation function AF-2 of nuclear receptors. EMBO J 1996, I 5(I 4):3667-3675.

39. Lee $\mathrm{CH}$, Chinpaisal $\mathrm{C}$, Wei LN: Cloning and characterization of mouse RIP I 40, a corepressor for nuclear orphan receptor TR2. Mol Cell Biol I 998, I 8(I I):6745-6755.

40. Robker RL, Russell DL, Espey LL, Lydon JP, O'Malley BW, Richards JS: Progesterone-regulated genes in the ovulation process: ADAMTS-I and cathepsin L proteases. Proc Natl Acad Sci U S A 2000, 97(9):4689-4694.

4I. Chappell PE, Lydon JP, Conneely OM, O'Malley BW, Levine JE: Endocrine defects in mice carrying a null mutation for the progesterone receptor gene. Endocrinology 1997, 138(10):4147-4I52.

Publish with Bio Med Central and every scientist can read your work free of charge

"BioMed Central will be the most significant development for disseminating the results of biomedical research in our lifetime. "

Sir Paul Nurse, Cancer Research UK

Your research papers will be:

- available free of charge to the entire biomedical community

- peer reviewed and published immediately upon acceptance

- cited in PubMed and archived on PubMed Central

- yours - you keep the copyright

Submit your manuscript here:

http://www.biomedcentral.com/info/publishing_adv.asp
BioMedcentral 